\title{
PENGARUH PENERAPAN MEDIA PEMBELAJARAN VIDEO TUTORIAL TERHADAP PENINGKATAN KEMAMPUAN TEKNIK DASAR TENDANGAN DEPAN PENCAK SILAT
}

\author{
Tatang Suryadin ${ }^{1}$ dan Radiko ${ }^{2}$ \\ Universitas Majalengka, Indonesia \\ Ttngsuryadin@gmail.com
}

\begin{abstract}
ABSTRAK. Penelitian ini mengkaji pengaruh media pembelajaran video tutorial terhadap peningkatan kemampuan teknik dasar tendangan depan pencak silat metode penelitian yang digunakan adalah metode eksperimen dalam bentuk one group pretest and posttest Populasi dengan jumlah 324 siswa. Teknik pengambilan sampel menggunakan Simple Random Sampling. Desain penelitian menggunakan One Group Pretest Posttest. Sampel penelitian dengan jumlah 30 siswa. Metode yang digunakan adalah eksperimen. Teknik pengumpulan data menggunakan tes rubrik penilaian keterampilan tendangan depan pada pencak silat. Teknik pengolahan dan analisis data menggunakan SPSS 24 Secara pengulasan data hasil rata-rata pada tes awal yaitu 64.4 dan setelah peneliti memberikan treatment dengan penerapan video tutorial terdapat peningkatan data hasil tes siswa yaitu dengan rata-rata 69.4. Dengan rata-rata selisih pada tes awal dan tes akhir yaitu 4.70. Berdasarkan nilai t hitung yang diperoleh pada hasil uji hipotesis adalah t- Hitung $=11.702$ lebih besar daripada nilai $\mathrm{t}$-Tabel $=1.697$. Maka hipotesis H1 diterima. Dengan demikian hipotesis penelitian tendangan depan pencak silat dapat diterima. Dengan demikian, dapat peneliti simpulkan bahwa penggunaan video tutorial berpengaruh signifikan terhadap kemampuan teknik dasar tendangan depan pencak silat pada siswa kelas X di SMA Negeri 1 Krangkeng Indramayu. Adapun saran-saran penulis ingin sampaikan adalah kepada pelatih dan guru pendidikan jasmani hendaknya memanfaatkan media belajar menggunakan video tutorial dalam melakukan proses pembelajaran dan kepada peneliti lain, untuk melakukan penelitian lebih lanjut dengan populasi yang digunakan lebih luas agar dapat membuktikan hasil yang lebih nyata.
\end{abstract}

Kata Kunci: Video Tutorial; Teknik Dasar Tendangan Depan; Pencak Silat.

\section{Pendahuluan}

Pencak silat merupakan salah satu materi yang diajarkan dalam Pendidikan jasmani di sekolah. Salah satu teknik dalam pencak silat adalah tendangan Tendangan memiliki beberapa macam tendangan. Seperti tendangan lurus, tendangan sabit, tendangan jejag, tendangan $\mathrm{T}$ dan tendangan belakang" Dari beberapa tendangan di atas, tendangan depan merupakan tendangan yang paling mudah digunakan dalam melakukan serangan saat berhadapan dengan lawan.

Menurut Kriswanto (2015) mengungkapkan bahwa: "Tendangan depan adalah tendangan yang menggunakan ujung kaki dengan tungkai lurus. Bagian kaki yang kena saat menendang adalah pangkal bagian dalam jari-jari kaki. Posisi badan menghadap ke sasaran”. Berdasarkan pendapat di atas, dapat disimpulkan bahwa teknik tendangan depan merupakan serangan yang menggunakan kaki dengan arah tendangan lurus ke depan dengan sasaran ulu hati dan dagu. Agar memiliki tendangan yang optimal dan benar. Penendang harus menguasai teknik tendangan depan dari posisi badan, kaki, dan kaki pada saat menendang. 
Ada beberapa temuan permasalahan atau kendala siswa dalam mempelajari teknik tendangan depan pencak silat diantaranya rangkaian gerakan tendangan depan yang benar masih menyulitkan siswa dalam mempelajarinya. Dengan menggunakan metode ceramah dan demontrasi ternyata tidak cukup sebagai strategi dalam menyampaikan poin utama bagaimana tendangan itu dilakukan. Permasalahan itu mengakibatkan hasil belajar siswa yang masih belum maksimal. Oleh karena itu, peneliti berupaya untuk memecahkan dan memperbaiki teknik tendangan depan tersebut.

Salah satu solusinya adalah dengan penggunaan media pembelajaran video tutorial. Menurut Arsyad (2016 menjelaskan bahwa: "Media pembelajaran adalah segala sesuatu yang dapat digunakan untuk menyampaikan pesan atau informasi dalam proses belajar mengajar sehingga dapat merangsang perhatian dan minat siswa dalam belajar." Adapun media pembelajaran yang peneliti gunakan yaitu dengan memanfaatkan perkembangan teknologi untuk mempermudah siswa dalam menyerap ilmu dan informasi dengan mudah melalui teknologi tersebut. Media pembelajaran yang peneliti terapkan dengan dengan menggunakan video tutorial. Menurut Aripin (2009) "Video tutorial merupakan panduan tentang cara menjelaskan sesuatu, baik materi pembelajaran atau pelatihan (training) maupun pengoperasian suatu sistem yang dikemas dalam bentuk video".

Kedudukan fungsi video tutorial dalam pembelajaran adalah sebagai media untuk memberikan feedback. Pentingnya feedback dalam pembelajaran diungkapkan Suheman (2009) bahwa:

Beberapa keuntungan penggunaan feedback antara lain sebagai berikut: 1) Mendorong siswa terus berlatih, feedback memberi tahu kepada siswa secara tidak langsung bahwa latihannya selalu dilihat atau diperhatikan oleh gurunya, 2) Mencerminkan perilaku guru yang efektif untuk memberikanfeedback, guru cenderung harus berjalanjalan untuk memantau dan melihat aktivitas belajar yang dilakukan oleh setiap anak di sekitar tempat latihan, 3) Membantu anak didik untuk menilai penampilan yang tidak bisa dilihat dan dirasakan oleh dirinya sendiri, 4) Mendorong guru untuk menilai seberapa relevan dan seberapa cepat setiap anak sudah belajar keterampilan seperti yang diinginkan oleh gurunya.

Berdasarkan paparan di atas, tujuan penelitian ini adalah untuk mengetahui pengaruh penerapan media pembelajaran video tutorial terhadap peningkatan kemampuan teknik dasar tendangan depan pencak silat.

\section{Metode Penelitian}

Metode penelitian yang digunakan dalam penelitian ini adalah metode eksperimen. Desain penelitian yang digunakan dalam penelitian ini ialah one group pretest posttest design. Desain 
ini digunakan sesuai dengan tujuan yang hendak dicapai yaitu ingin mengetahui pengaruh penggunaan media pembelajaran video tutorial terhadap peningkatan kemampuan teknik dasar tendangan depan pencak silat.

Populasi dalam penelitan ini adalah seluruh siswa kelas X di SMA Negeri 1 Krangkeng yang berjumlah 273 siswa. Adapun sampel dalam penelitian ini dengan menggunakan teknik Simple Random Sampling. Hal ini dijelaskan menurut Sugiyono (2014) menjelaskan bahwa: "Simple random sampling adalah teknik penentuan sampel dengan cara pengambilan anggota sampel dari populasi dilakukan secara acak tanpa memperhatikan strata yang ada dalam populasi itu. Cara demikian dilakukan bila populasi homogen." Teknik pengambilan sampel kelas secara acak melalui undian dari semua populasi yaitu siswa kelas X. Sebelumnya diberikan nomor urut terlebih dahulu dari nomor 1 sampai 10, kemudian setelah itu dilakukan pengambilan sampel dengan teknik simple random sampling didapatkan nomor 5 sebagai kelas eksperimen yaitu kelas X-5 MIPA dengan jumlah siswa sebanyak 30 siswa. Dengan demikian sampel dalam penelitian ini yaitu pada kelas X-5 MIPA dengan jumlah siswa sebanyak 30 siswa.

Adapun instrumen yang digunakan dalam peneliitian ini tes tendangan yang merujuk pada pendapat Lubis dan Wardoyo (2013) Tujuan: untuk mengetahui kemampuan tendangan pencak silat siswa (untuk teknik tendangan depan, samping, dan sabit). Dengan indikator sebagai berikut:

Tabel 1

Indikator Tendangan Lurus

\begin{tabular}{|c|l|}
\hline No & \multicolumn{1}{|c|}{ Indikator Tendangan Lurus } \\
\hline 1 & Posisi sikap pasang (awal) \\
\hline 2 & Lutut diangkat terlebih dahulu (lk 100 derajat) \\
\hline 3 & Posisi badan saat angkatan kaki dalam keadaan seimbang \\
\hline 4 & Melepaskan kaki dengan lurus \\
\hline 5 & Posisi badan saat lepasan kaki dalam keadaan seimbang \\
\hline 6 & Posisi kedua tangan merapat dengan badan \\
\hline 7 & Menarik kaki dengan lutut merapat (lk 100 derajat) \\
\hline 8 & Posisi badaan saat lutut merapat seimbang \\
\hline 9 & Posisi kedua tangan di depan dada \\
\hline 10 & Kembali ke sikap pasang dalam keadaan seimbang \\
\hline
\end{tabular}


Teknik analisis data pengolahan data pada penelitian ini menggunakan SPSS 24. Pengolahan analisis data yang ditempuh adalah uji normalitas, uji homogenitas dan uji hipotesis.

\section{Hasil dan Pembahasan}

Hasil penelitian ditampilkan dalam bentuk deskriptif statistik, hasilnya dapat dilihat pada tabel 2 sebagai berikut:

Tabel 2

Statistik Dekriptif

Kemampuan Tendangan Depan

\begin{tabular}{|l|l|r|r|r|}
\hline \multicolumn{5}{|c|}{ Statistics } \\
\hline \multirow{2}{*}{$N$} & PRETEST & POSTEST & \multicolumn{1}{l|}{ PENINGKATAN } \\
\hline & Valid & 30 & 30 & 30 \\
\cline { 2 - 5 } & Missing & 0 & 0 & 0 \\
\hline Mean & 64,4000 & 69,4333 & 4,7000 \\
\hline Median & 66,5000 & 70,5000 & 4,0000 \\
\hline Mode & $65,00^{\mathrm{a}}$ & 70,00 & 4,00 \\
\hline Std. Deviation & 7,59582 & 7,75790 & 2,39468 \\
\hline Variance & 57,697 & 60,185 & 5,734 \\
\hline Minimum & 46,00 & 52,00 & 1,00 \\
\hline Maximum & 74,00 & 84,00 & 11,00 \\
\hline
\end{tabular}

Hasil pengujian normalitas pada tes awal dan tes akhir dapat dilihat pada tabel 3 dibawah ini:

Tabel 3

Hasil Pengujian Normalitas

\begin{tabular}{|c|c|c|c|c|}
\hline Periode Tes & N & Sig $(\boldsymbol{\rho})$ & $\boldsymbol{\alpha}$ & Hasil \\
\hline Tes Awal Tendangan Depan & \multirow{2}{*}{30} & 0.057 & 0.05 & Normal \\
\cline { 4 - 6 } & & 1.112 & 0.05 & Normal \\
\hline Tes Akhir Tendangan Depan & & &
\end{tabular}

Dari tabel 3 di atas, terlihat Asymp Sig (2-tailed) sebesar $0.057>0,05$ atau probabalitas 0,057 lebih besar dari 0,05, sehingga hipotesis nol diterima, dengan demikian tes awal tendangan depan berdistribusi normal.

Sedangkan hasil data tes akhir tendangan depan terlihat Asymp Sig (2-tailed) sebesar $1.112>0,05$ atau probabalitas 1.112 lebih besar dari 0,05, sehingga hipotesis nol diterima, dengan demikian tes akhir tendangan depan berdistribusi normal. Uji homogenitas dilakukan menggunakan lavene test $(\mathrm{a}=0.05)$ dengan ketentuan bila nilai sig, atau nilai probabilitas lebih besar dari 0.05 (sig > 0.05) maka data tersebut homogen, adapun hasilnya sebagai berikut. 
Tabel 4

Hasil Pengujian Homogenitas Dua Varians

\begin{tabular}{|l|c|c|l|r|}
\hline \multicolumn{1}{|c|}{ Uraian } & N & F- & F-Tabel & Hasil \\
\hline $\begin{array}{l}\text { Tendangan Depan Pencak } \\
\text { Silat }\end{array}$ & 30 & 6.447 & 4.20 & Homogen \\
\hline
\end{tabular}

Dari tabel 4 di atas didapat tes awal dan akhir tendangan depan pencak silat yaitu FHitung $=6.447$ dengan taraf nyata $\alpha=0,05$ sedangkan dari daftar Tabel yaitu Fhitung $=6.447$ yang lebih besar dari pada Ftabel $=4.20$ sehingga hipotesis nol diterima artinya ada tendangan depan pencak silat pada sampel homogen. Hasil pengujian uji hipotesis dengan paired sample t test dapat terlihat pada tabel 5 di bawah ini:

Tabel 5

Hasil Pengujian Hipotesis

\begin{tabular}{|c|c|l|l|c|c|c|}
\hline Uraian & $\mathbf{N}$ & t-Hitung & t-Tabel & Sig $(p)$ & $\boldsymbol{\alpha}$ & Hasil \\
\hline $\begin{array}{c}\text { Selisih Tes Awal } \\
\text { dan Tes Akhir }\end{array}$ & 30 & 11.702 & 1.697 & 0,000 & 0,025 & Signifikan \\
Kelompok & & & & & & \\
Eksperimen & & & & & & \\
\hline
\end{tabular}

Karena nilai t-Hitung $=11.702$ lebih besar daripada nilai t-Tabel $=1.697$ pada batas penolakan hipotesis. Maka hipotesis Ho diterima. Dengan video tutorial mempunyai perbedaan yang sangat berarti atau hipotesis diterima. Karena $0,000<0,025$, dengan demikian Ho ditolak dapat disimpulkan bahwa rata-rata kemampuan teknik dasar tendangan depan sebelum dan sesudah diberikan video tutorial meningkat secara signifikan. Berdasarkan hal tersebut bisa disimpulkan bahwa penggunaan video tutorial memberikan pengaruh yang signifikan terhadap kemampuan teknik dasar tendangan depan pada siswa kelas X di SMA 1 Negeri Krangkeng Indramayu.

\section{Diskusi Hasil Penelitian}

Pemakaian media pembelajaran dalam proses belajar mengajar dapat membangkitkan keinginan dan minat baru, membangkitkan motivasi dan rangsangan kegiatan belajar, dan bahkan membawa pengaruh psikologis terhadap siswa. Seperti halnya pembelajaran menggunakan video tutorial.

Kaitannya video tutorial dengan siswa SMA yang masuk pada masa remaja Menurut Lerner dan Hustlsch dalam Desmita (2014) mengemukakan bahwa: Kemampuankemampuan kognitif tersebut akan semakin berkembang hingga anak memasuki tahap pemikiran operasional formal (formal operational thought), yakni suatu tahap 
perkembangan kognitif yang dimulai pada usia kira-kira 11 atau 12 tahun dan terus berlanjut sampai remaja mencapai masa tenang atau dewasa.

Pada masa remaja kemampuan untuk berpikir secara abstrak, menalar, secara logis sudah berkembang. Materi pembelajaran dalam video tutorial bisa dijadikan bahan informasi untuk diamati, dianalisa oleh mereka. Video tutorial merupakan media proses pembelajaran yang dikemas dalam video dengan tujuan untuk mempermudah siswa dalam memahami pembelajaran. Hal ini, seperti diungkapkan menurut Aripin (2009) "Video tutorial merupakan panduan tentang cara menjelaskan sesuatu, baik materi pembelajaran atau pelatihan (training) maupun pengoperasian suatu sistem yang dikemas dalam bentuk video.”

Penggunaan video tutorial sangat membantu keaktifan proses pembelajaran dan penyampaian pesan dan isi pelajaran tendangan depan pencak silat tersebut. Selain itu, video tutorial dapat membantu siswa dengan menyajikan data dengan menarik dan terpercaya, memudahkan penafsiran data sehingga dapat meningkatkan pemahaman tentang fase-fase pada gerakan tendangan depan pencak silat yang benar. Sehingga, pengunaan video tutorial ini akan mempermudah siswa dalam menyerap pengetahuan tentang rangkaian tendangan depan yang benar pada teknik tendangan depan tersebut. Dari kegiatan tersebut akan memberikan pengalaman belajar siswa pada teknik tendangan depan melalui video tutorial, sehingga dapat memperbaiki dan meningkatkan kemampuan tendangan depan pencak silat.

Berdasarkan hasil tes tendangan depan dengan menggunakan video tutorial adanya peningkatan terhadap kemampuan teknik dasar tendangan depan pada siswa kelas X di SMA 1 Negeri Krangkeng Indramayu. Berdasarkan nilai t hitung yang diperoleh, menggunakan video tutorial adanya pengaruh signifikasn terhadap hasil kemampuan teknik dasar tendangan depan pada siswa kelas X di SMA 1 Negeri Krangkeng Indramayu atau hipotesis penelitian dapat diterima.

\section{Daftar Pustaka}

Arifin, J. 2017). SPSS 24 Untuk Peneltian dan Skripsi. Jakarta: PT Rineka Cipta. Arikunto, S. (2013). Prosedur Penelitian. Jakarta: PT Rineka Cipta.

Aripin b.c. 2009. Step By Step Membuat Video Tutorial Menggunakan Camtasia Studio. Oase Media. Bandung.

Arsyad, A. (2016). Media Pembelajaran Edisi Revisi. PT Raja Grafindo Persada. Jakarta.

Desmita. (2009). Psikologi Perkembangan Peserta Didik. Bandung: PT RemajaRosdakarya.

Kriswanto, E. S. (2015). Pencak Silat. Pustaka Baru Press. Yogyakarta.

Lubis, Johansyah dan Hendro Wardoyo. 2014. Pencak Silat Paduan Edisi Kedua. Jakarta: PT. Raja Grafindo Persada.

Sugiyono. (2014). Metode Penelitian Kuantitatif Kualitatif dan $R \& D$. Bandung: CV Alfabeta.

Suherman, A. (2009). Revitalisasai Pengajaran dalam Pendidikan Jasmani. Bandung: CV. Bintang Warli Arika 